O. V. Gaidai', Ye. Yu. Zhyhadlo1, I. A. Levandovskiy¹, O. G. Sidorenko1, O. V. Shishkin², S. V. Shishkina², Yu. V. Rassukana ${ }^{1,3}$

${ }^{1}$ National Technical University of Ukraine "Igor Sikorsky Kyiv Polytechnic Institute", Ukraine 37, Peremohy Ave., Kyiv, 03056, Ukraine. E-mail: juvivi@ukr.net

2 State Scientific Institution "Institute for Single Crystals" of the National Academy of Sciences of Ukraine, Ukraine

${ }^{3}$ Institute of Organic Chemistry of the National Academy of Sciences of Ukraine, Ukraine

\title{
Reactions of Cookson's diketone with potassium halides in the polyphosphoric acid medium
}

Aim. To study the rearrangement of Cookson's diketone by the action of potassium halides under conditions of polyphosphoric acid catalysis.

Results and discussion. Chemical behaviour of Cookson's diketone $\left(C_{S}\right.$-trishomocubane-8,11-dione $)$ in the reactions with potassium halides $(\mathrm{KCl}, \mathrm{KBr}, \mathrm{KI})$ in the polyphosphoric acid (PPA) medium have been studied. When treated with the KI/PPA mixture Cookson's diketone undergoes reduction leading to tetracyclo[6.3.0.0.4,11.05,9]undecane-2,7dione. The use of $\mathrm{KBr}$ instead of $\mathrm{KI}$ leads to formal addition of $\mathrm{HBr}$ to the cyclobutane ring of $C_{s}$-trishomocubane8,11-dione and gives 3-bromotetracyclo[6.3.0.0 $\left.0^{4,11} \cdot 0^{5,9}\right]$ undecane-2,7-dione. The general scheme of the cycle opening mechanism has been proposed. In the case of using the KCI/PPA mixture the reaction does not occur.

Experimental part. The structure and composition of compounds were proved by the methods of ${ }^{1} \mathrm{H}$ and ${ }^{13} \mathrm{C}$ NMR-spectroscopy, and also X-ray diffraction analysis. Elemental analysis was performed for the compounds obtained.

Conclusions. It has been shown that hydrohalic acids generated in situ under the reaction conditions do not induce the rearrangement of Cookson's diketone to the $D_{3}$-trishomocubane system. The cyclobutane ring opening and reduction take place instead.

Key words: Cookson's diketone; polyphosphoric acid; ring opening; $C_{s}$-trishomocubane; reduction

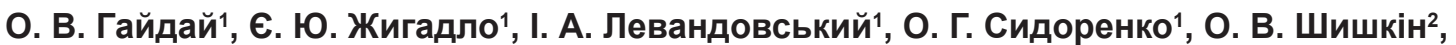

С. В. Шишкіна ${ }^{2}$ Ю. В. Рассукана ${ }^{1,3}$

${ }^{1}$ НТУУ «Київський політехнічний інститут імені Ігоря Сікорського», Україна

${ }^{2}$ НTК «ІІнститут монокристалів» НАН України, Україна

${ }^{3}$ Інститут органічної хімії НАН України, Україна

Реакції дикетону Куксона з галогенідами калію в середовищі поліфосфорної кислоти

Мета. Дослідити перегрупування дикетону Куксона під дією галогенідів калію в умовах каталізу поліфосфорною кислотою.

Результати та їх обговорення. Вивчено хімічну поведінку дикетону Куксона $\left(C_{s}\right.$-трисгомокубан-8,11діону) в реакції з галогенідами калію $(\mathrm{KCl}, \mathrm{KBr}, \mathrm{KI})$ в середовищі поліфосфорної кислоти (PРA). При обробці йодидом калію в середовищі поліфосфорної кислоти дикетон Куксона вступає в реакцію відновлення, яка приводить до утворення тетрацикло[6.3.0.0.4,11.05,9]ундекан-2,7-діону. Використання KBr замість KI приводить до формального приєднання $\mathrm{HBr}$ до циклобутанового кільця $C_{s}$-трисгомокубан-8,11-діону, в результаті чого утворюється 3-бромтетрацикло[6.3.0.04,11.05,9]ундекан-2,7-діон. Запропоновано загальну схему механізму розкриття циклу. У випадку використання системи КСІ/РPА реакція не відбувається.

Експериментальна частина. Структуру та склад сполук було доведено методами ${ }^{1} \mathrm{H}$ та ${ }^{13} \mathrm{C}$ ЯМР-спектроскопії, а також рентгеноструктурним аналізом. Проведено елементний аналіз одержаних сполук.

Висновки. Показано, що галогеноводневі кислоти, що утворюються in situ при змішуванні галогенідів калію та поліфосфорної кислоти, замість перегрупування дикетону Куксона в похідні $D_{3}$-трисгомокубану спричиняють відновлення каркасу з розкриттям циклобутанового фрагмента.

Ключові слова: дикетон Куксона; поліфосфрорна кислота; розкриття циклу; $C_{S}$-трисгомокубан; відновлення

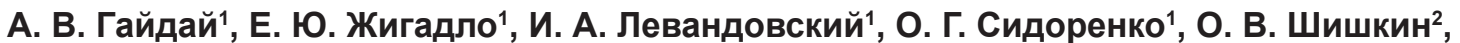

С. В. Шишкина ${ }^{2}$ Ю. В. Рассукана ${ }^{1,3}$

${ }^{1}$ НТУУ «Киевский политехнический институт имени Игоря Сикорского», Украина

${ }^{2}$ НТК «Институт монокристаллов» НАН Украины, Украина

${ }^{3}$ Институт органической химии НАН Украины, Украина

Реакции дикетона Куксона с галогенидами калия в среде полифосфорной кислоты

Цель. Исследовать перегруппировку дикетонов Куксона под действием галогенидов калия в условиях катализа полифосфорной кислотой.

Результаты и их обсуждение. Изучено химическое поведение дикетона Куксона $\left(C_{s}\right.$-трисгомокубан8,11-диона) в реакции с галогенидами калия (KCI, KBr, $\mathrm{KI}$ ) в среде полифосфорной кислоты (PPA). При обработке йодидом калия в среде полифосфорной кислоты дикетон Куксона вступает в реакцию восстановления, которая приводит к образованию тетрацикло[6.3.0.0.4,11.05,9]ундекан-2,7-диона. Использование $\mathrm{KBr}$ вместо KI приводит к формальному присоединению $\mathrm{HBr}$ по циклобутановому кольцу $C_{S}$-трисгомокубан8,11-диона, в результате чего образуется 3-бромтетрацикло [6.3.0.04,11.05,9]ундекан-2,7-дион. Предложена общая схема механизма раскрытия цикла. В случае использования системы КСІ/PPA реакция не происходит. 
Экспериментальная часть. Структура и состав соединений были подтверждены методами ${ }^{1} \mathrm{H}$ и ${ }^{13} \mathrm{C}$ ЯМР-спектроскопии, а также рентгеноструктурным анализом. Проведен элементный анализ полученных соединений.

Выводы. Показано, что галогеноводородные кислоты, образующиеся in situ при смешивании галогенидов калия и полифосфорной кислоты, вместо перегруппировки дикетона Куксона в производные $D_{3}$-трисгомокубана приводzт к восстановлению каркаса с раскрытием циклобутанового фрагмента.

Ключевые слова: дикетон Куксона; полифоссрорная кислота; раскрытие цикла; $C_{\mathrm{s}}$-трисгомокубан; восстановление

The rearrangement of $C_{s}$-trishomocubane (pentacyclo[5.4.0.0. $\left.0^{2,6} \cdot 0^{3,10} \cdot 0^{5,9}\right]$ undecane) derivatives (1, Fig. 1) under acidic conditions is the most general approach for the synthesis of $D_{3}$-trishomocubanes (2, Fig. 1). However, the majority of the methods reported in the literature involve the rearrangement of the substituted 8-hydroxy- or 8,11-dihydroxy- $C_{s}$-trishomocubanes (3, 4, Fig. 1) [1]. The rearrangement of the corresponding ketones is still insufficiently studied [1] although both cage ketones and products of their rearrangements are potentially useful for medicinal chemistry. So far, the only satisfactory reagent for the rearrangement of ketones is chlorosulfonic acid [2-4], which has rather low tolerance of functional groups and is not too easy to handle. Moreover, in case of substituted Cookson's diketones such rearrangement often proceeds non-selectively and affords hardly separable mixtures of polysubstituted $D_{3}$-trishomocubanes [5].

It is believed that the rearrangement of Cookson's diketone (5, Fig. 1) with chlorosulfonic acid involves a formal addition of $\mathrm{HCl}$ to the carbonyl group, further protonation and subsequent elimination of water. The cation thus formed is attacked by a nucleophile to give the $D_{3}$-trishomocubane system [2]. This means that any other strong Brønsted acid may induce the rearrangement. Aiming to find a convenient reagent for the rearrangement we tested the reactions of $C_{S}$-trishomocubane-8,11-dione (Cookson's diketone 5) [6] with a series of acidic reagents.

$C_{S}$-Trishomocubane-8,11-dione $\mathbf{5}$ was synthesized starting from commercially available quinone $\mathbf{6}$ and cyclopentadiene in two simple steps (Diels-Alder reaction and [2+2]-photocyclization) in the overall yield of 78\% [6] (Scheme 1).

First, we tried to perform the rearrangement of 5 using the procedures, which previously were successfully employed for the rearrangement of diol $\mathbf{4}$ $[7,8]$. Thus, diketone 5 was stirred for $16 \mathrm{~h}$ in hydro- halic acids $(\mathrm{HCl}, \mathrm{HBr}, \mathrm{HI})$ at elevated temperatures $\left(\approx 100^{\circ} \mathrm{C}\right)$. However, in all cases the reaction did not occur, and the started material was recovered.

At the same time, it is known that the KI/PPA system, where hydrogen iodide was generated in situ, was also used for the rearrangement of $C_{s}$-trishomocubane-8,11-diol 4. It was found that applying this literature procedure $\left(6 \mathrm{~h}, 100-110^{\circ} \mathrm{C}\right)[8]$ to diketone $\mathbf{5}$ gave a single product isolated with the yield of $60 \%$. Its physicochemical constants were in agreement with the literature data for tetracyclo[6.3.0.0.4,11.0 $\left.0^{5,9}\right]$ undecane-2,7-dione 8 [9]. Obviously, in this case reduction took place instead of the expected rearrangement to the $D_{3}$-trishomocubane system (Scheme 2). However, we were pleased to find that Cookson's diketone was reactive towards KX/PPA mixtures (Scheme 2).

Considering that $\mathrm{HI}$ was much more active reducing agent than $\mathrm{HBr}$ we assumed that the use of $\mathrm{KBr}$ instead of KI would allow us to avoid reduction. However, tetracyclo[6.3.0.0. $\left.{ }^{4,11} \cdot 0^{5,9}\right]$ undecane-2,7-dione 8 was formed in this case too, albeit in smaller amount (30\% in the crude mixture as judged by GC/MS). The main product $(70 \%$ in the crude mixture) was 3 -bromotetracyclo[6.3.0.0 $\left.0^{4,11} \cdot 0^{5,9}\right]$ undecane-2,7-dione 9 . Since tetracyclic bromodiketone 9 had quite similar NMRspectra compared to the possible product with the $D_{3}$-trishomocubane skeleton and the same molar mass, its structure was confirmed by the X-Ray single crystal structure analysis (Fig. 2). It should be noted that bromodiketone 9 was previously prepared from 5 in 3-step synthesis in the overall yield of $22 \%$ [10]. In unclear reasons, diketone 5 did not interact with $\mathrm{KCl}$ in the polyphosphoric acid medium even after continuous reflux (Scheme 3).

Considering the above facts and the suggested mechanisms previously reported for similar reactions [11-13] we proposed the scheme for the mechanism of the ring opening reaction. Initially, protonation of the carbonyl group takes place. The intermediate $\boldsymbol{A}$

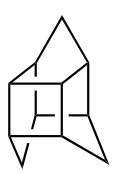

1

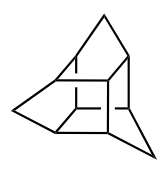

2

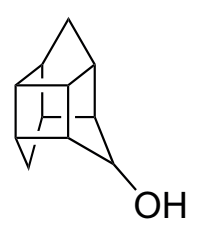

3

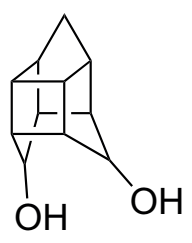

4

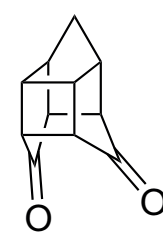

5

Fig. 1. $C_{S}$-trishomocubane 1, $D_{3}$-trishomocubane 2, 8-hydroxy- $\mathbf{3}$ and 8,11-dihydroxy- $C_{S}$-trishomocubanes 4 , Cookson's diketone 5 


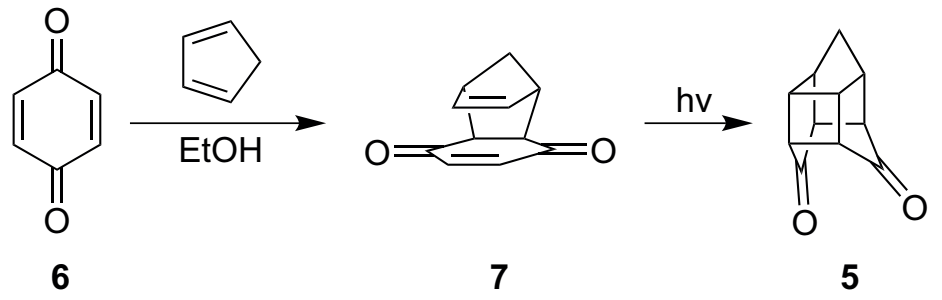

Scheme 1. The synthesis of $C_{S}$-trishomocubane-8,11-dione 5

obtained undergoes keto-enol tautomerism to form cation $\boldsymbol{B}$. Under $\mathrm{KBr} / \mathrm{PPA}$ conditions the cation can be either attacked by a bromide ion to form bromide 9, or undergo reduction with $\mathrm{HBr}$, while under KI/PPA conditions only reduction with HI occurs. Such mechanism would explain emergence of all the products which previously seemed to be atypical (Scheme 4).

\section{Experimental part}

${ }^{1} \mathrm{H}$ and ${ }^{13} \mathrm{C}$ NMR-spectra were recorded using Bruker Avance NMR spectrometers operating at 400 and $500 \mathrm{MHz}$ (101 and $126 \mathrm{MHz}$ for ${ }^{13} \mathrm{C}$ experiments). Chemical shifts were reported relative to the internal standard TMS $\left({ }^{1} \mathrm{H}\right)$. Melting points were uncorrected. Solvents were dried before use according to standard methods. Elemental analysis was performed in the analytical laboratory of the Institute of Organic Chemistry at the NAS of Ukraine.

The reaction of $C_{s}$-trishomocubane-8,11-dione with KI/PPA. We applied the procedure reported previously [8]. To $85 \% \mathrm{H}_{3} \mathrm{PO}_{4}(7.80 \mathrm{~g})$ in a round-bottom flask $(100 \mathrm{~mL})$ add $\mathrm{P}_{2} \mathrm{O}_{5}(5.90 \mathrm{~g}, 20.8 \mathrm{mmol})$. After the initial exothermic reaction had subsided add KI $(11.2 \mathrm{~g}, 67.5 \mathrm{mmol})$ and $C_{\mathrm{s}}$-trishomocubane-8,11-dione $5(2.00 \mathrm{~g}, 11.5 \mathrm{mmol})$. Fit the flask with a reflux condenser and a drying tube and stir for $6 \mathrm{~h}$ at

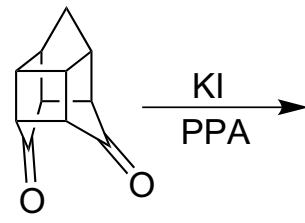

5

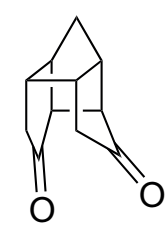

8
Scheme 2. The reaction of $C_{s}$-trishomocubane-8,11-dione $\mathbf{5}$ with $\mathrm{KI}$ in polyphosphoric acid

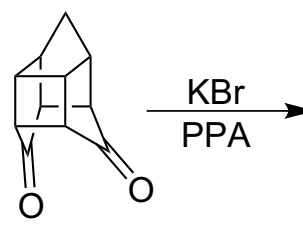

5

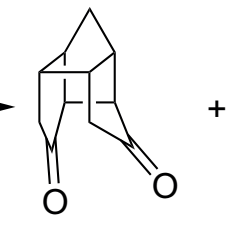

8

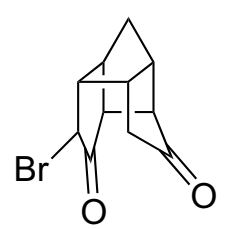

9
Scheme 3. The reaction of $C_{s}$-trishomocubane-8,11-dione 5 with $\mathrm{KBr}$ in polyphosphoric acid $105-110^{\circ} \mathrm{C}$. Transfer the cooled dark viscous mass to a separate funnel using dichloromethane and water. After extracting with dichloromethane wash the organic phase with $10 \%$ aqueous $\mathrm{Na}_{2} \mathrm{~S}_{2} \mathrm{O}_{3}(2 \times 10 \mathrm{~mL})$ and water $(2 \times 10 \mathrm{~mL})$, dry over $\mathrm{Na}_{2} \mathrm{SO}_{4}$, pass through a pad of $\mathrm{Al}_{2} \mathrm{O}_{3}$, and evaporate under reduced pressure to obtain $1.23 \mathrm{~g}(7.00 \mathrm{mmol}, 61 \%)$ of compound 8 . Physicochemical constants of compound $\mathbf{8}$ were in agreement with the literature data; M. p. $=253-256^{\circ} \mathrm{C}$ (lit. $255-257^{\circ} \mathrm{C}$ [9]).

The reaction of $C_{s}$-trishomocubane-8,11-dione with $\mathrm{KBr} / \mathrm{PPA}$. To $85 \% \mathrm{H}_{3} \mathrm{PO}_{4}(7.80 \mathrm{~g})$ in a roundbottom flask $(100 \mathrm{~mL})$ add $\mathrm{P}_{2} \mathrm{O}_{5}(5.90 \mathrm{~g}, 20.8 \mathrm{mmol})$. After the initial exothermic reaction had subsided, add $\mathrm{KBr}(8.03 \mathrm{~g}, 67.5 \mathrm{mmol})$ and $C_{\mathrm{s}}$-trishomocubane8,11-dione 5 ( $2.00 \mathrm{~g}, 11.5 \mathrm{mmol})$. Fit the flask with a reflux condenser and a drying tube and stir for $6 \mathrm{~h}$ at $105-110^{\circ} \mathrm{C}$. Transfer the cooled, dark, viscous mass to a separatory funnel using dichloromethane and water. After extracting with dichloromethane, wash the organic phase with $10 \%$ aqueous $\mathrm{Na}_{2} \mathrm{~S}_{2} \mathrm{O}_{3}(2 \times 10 \mathrm{~mL})$ and water $(2 \times 10 \mathrm{~mL})$, dry over $\mathrm{Na}_{2} \mathrm{SO}_{4}$, and evaporate under reduced pressure. Subject the residue to silica gel column chromatography (hexane/ethyl acetate $5: 1)$ to give $0.536 \mathrm{~g}(3.04 \mathrm{mmol}, 26 \%)$ of compound 8 and $1.85 \mathrm{~g}(7.25 \mathrm{mmol}, 63 \%)$ of compound 9.

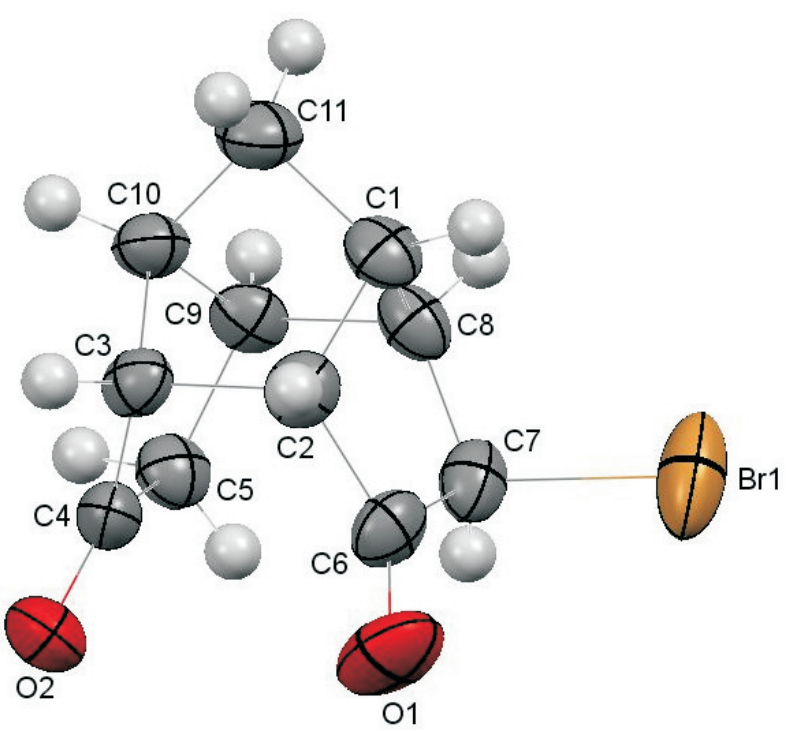

Fig. 2. The structure of 3-bromotetracyclo[6-3.0.0 $\left.0^{4,11} \cdot 0^{5,9}\right]$ undecane2,7-dione 9 according to X-ray diffraction data. Thermal ellipsoids are shown at $50 \%$ probability level 


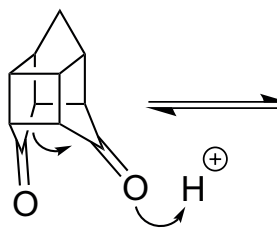

5

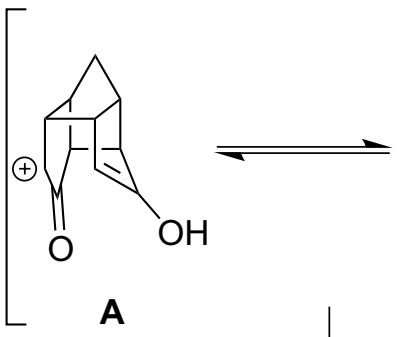

\begin{tabular}{|c|} 
B \\
reduction \\
with $\mathrm{HBr}$ or $\mathrm{HI}$
\end{tabular}

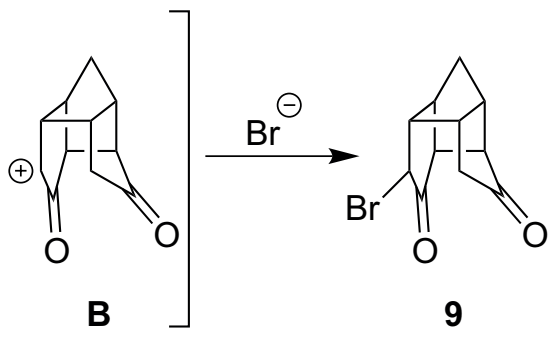

9

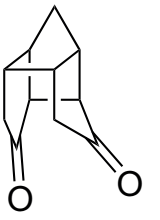

8

Scheme 4. The scheme of the mechanism proposed for the reaction of Cookson's diketone $\mathbf{5}$ with potassium halides in the polyphosphoric acid medium

Physicochemical constants of compound 9 were in agreement with the literature data; M. p. $=120-121^{\circ} \mathrm{C}$ (lit. $122-123^{\circ} \mathrm{C}$ ) [14].

The X-ray crystal structure experimental details. The colorless crystals of $\mathbf{9}\left(\mathrm{C}_{11} \mathrm{H}_{11} \mathrm{O}_{2} \mathrm{Br}\right)$ are monoclinic. At $293 \mathrm{Ka}=11.4462(6), b=7.5417(4), c=11.7850(5) \AA$, $\beta=104.62(5)^{\circ}, V=984.40(8) \AA^{3}, M_{r}=255.11, Z=4$, space group $P 2_{1} / n, d_{\text {calc }}=1.721 \mathrm{~g} / \mathrm{cm}^{3}, \mu\left(\mathrm{MoK}_{\alpha}\right)=$ $4.144 \mathrm{~mm}^{-1}, F(000)=512$. Intensities of 9086 reflections (2867 independent, $R_{\text {int }}=0.030$ ) were measured on a "Xcalibur-3" diffractometer (graphite monochromated $\mathrm{MoK}_{\alpha}$ radiation, CCD detector, $\omega$-scaning, $2 \Theta_{\max }=60^{\circ}$ ). The structure was solved by the direct method using a SHELXTL package [15]. The absorption correction was done using the multi-scan method $\left(T_{\min }=0.575, T_{\max }=0.682\right)$. Positions of hydrogen atoms were located in electron density difference maps and refined using isotropic approximation. Full-matrix least-squares refinement against $F^{2}$ in anisotropic approximation for non-hydrogen atoms using 2835 reflections was converged to $w R_{2}=0.146\left(R_{1}=0.053\right.$ for 2047 reflections with $F>4 \sigma(F), \mathrm{S}=1.086)$. The final atomic coordinates and crystallographic data for molecule 9 were deposited to with the Cambridge Crys- tallographic Data Centre, 12 Union Road, CB2 1EZ, UK (fax: +44-1223-336033; e-mail: deposit@ccdc. cam.ac.uk) and were available on request quoting the deposition numbers CCDC 1819442).

\section{Conclusions}

The reactions of Cookson's diketone with potassium halides in the polyphosphoric acid medium have been studied. It has been found that hydrohalic acids generated in situ under the reaction conditions do not induce the rearrangement of Cookson's diketone to the $D_{3}$-trishomocubane system. Therefore, the use of the KI/PPA mixture for the reaction leads to reduction of the starting diketone giving tetracyclo[6.3.0.0.4,11.0 $\left.0^{5,9}\right]$ undecane-2,7-dione. The use of the KBr/PPA mixture leads to formal addition of $\mathrm{HBr}$ to the cyclobutane ring and gives 3-bromotetracyclo[6.3.0.0 $\left.0^{4,11} .0^{5,9}\right]$ undecane-2,7-dione. Though the target process is accompanied with the partial reduction and the admixture, tetracyclo[6.3.0.0.4,11.0 $\left.0^{5,9}\right]$ undecane-2,7-dione is also formed. Hydrogen chloride generated from $\mathrm{KCl}$ and PPA does not react with Cookson's diketone.

Conflict of interests: authors have no conflict of interests to declare.

\section{References}

1. Levandovsky, I. A.; Sharapa, D. I.; Cherenkova, O. A.; Gaidai, A. V.; Shubina, T. E. The chemistry of $D_{3}$-trishomocubane. Russ. Chem. Rev. 2010, 79 (11), 1005-1026. http://doi.org/10.1070/RC2010v079n11ABEH004119.

2. Sharapa, D. I.; Gayday, A. V.; Mitlenko, A. G.; Levandovskiy, I. A.; Shubina, T. E. A Convenient Road to 1-Chloropentacycloundecanes - A Joint Experimental and Computational Investigation. Eur. J. Org. Chem. 2011, 2011 (13), 2554-2561. https://doi.org/10.1002/ejoc.201001731.

3. Mishura, A.; Sklyarova, A.; Sharapa, D.; Levandovsky, I.; Serafin, M.; Fokin, A.; Rodionov, V. Stereoselective preparation of mono- and bis-derivatives of pentacyclo[6.3.0.02.6.03.10.05.9] undecane ( $D_{3}$-trishomocubane). Open Chemistry 2013, 11 (12), 2144-2150. https://doi.org/10.2478/ s11532-013-0339-8.

4. Tolstikov, G. A.; Lerman, B. M.; Galin, F. Z.; Struchkov, Y. T.; Andrianov, V. G. Synthesis of trishomocubane and dihomobasketane derivatives via the skeletal. Rearrangement under the action of chlorosulphonic acid. Tetrahedron Lett. 1978, 19 (43), 4145-4148. https://doi.org/10.1016/ S0040-4039(01)95166-4.

5. Zhyhadlo, Y. Y.; Gaidai, A. V.; Sharapa, D. I.; Mitlenko, A. G.; Shishkin, O. V.; Shishkina, S. V.; Levandovskiy, I. A.; Fokin, A. A. Functionalised Cookson's Diketones in Chlorosulfonic Acid: Towards Polysubstituted $D_{3}$-Trishomocubanes. Journal of Chemical Research 2017, 41 (12), 718-721. https:// doi.org/10.3184/174751917X15125690124264.

The research was carried out according to the budget theme of the Ministry of Education and Science of Ukraine "Development of methods for functionalization of $D_{3}$-trishomocubane" (the state registration No. 0111U003972; the research period 2012-2016). 
6. Cookson, R. C.; Crundwell, E.; Hill, R. R.; Hudec, J. 586. Photochemical cyclisation of Diels-Alder adducts. Journal of the Chemical Society (Resumed) 1964, (0), 3062-3075. https://doi.org/10.1039/JR9640003062.

7. Kent, G. J.; Godleski, S. A.; Osawa, E.; Schleyer, P. v. R. Syntheses and relative stability of $\left(D_{3}\right)$-trishomocubane (pentacyclo[6.3.0.0 $\left.0^{2,6} .0^{3,10} .0^{5,9}\right]$ undecane), the pentacycloundecane stabilomer. J. Org. Chem. 1977, 42 (24), 3852-3859. https://doi.org/10.1021/jo00444a012.

8. Smith, E. C.; Barborak, J. C. Syntheses of the pentacyclo[6.3.0.0 $\left.0^{2,6} \cdot 0^{3,10} \cdot 0^{5,9}\right]$ undecyl (trishomocubyl) and tetracyclo[6.3.0.0 $\left.0^{4,11} \cdot 0^{5,9}\right]$ undeca-2,6-dienyl (homohypostrophenyl) systems. J. Org. Chem. 1976, 41 (8), 1433-1437. https://doi.org/10.1021/jo00870a032.

9. Butler, D. N.; Munshaw, T. J. The synthesis of 2,3,5,6-endo,endo,endo,endo-tetrakis-substituted bicyclo[2.2.1]heptanes. Can. J. Chem. 1981, 59 (24), 3365-3371. https://doi.org/10.1139/v81-500.

10. Kotha, S.; Manivannan, E.; Sreenivasachary, N. Allylation of caged diketones via fragmentation methodology. J. Chem. Soc., Perkin Trans. 1 1999, (19), 2845-2848. https://doi.org/10.1039/A902629K.

11. Dobmeier, M.; Herrmann, J. M.; Lenoir, D.; König, B. Reduction of benzylic alcohols and $\alpha$-hydroxycarbonyl compounds by hydriodic acid in a biphasic reaction medium. Beilstein Journal of Organic Chemistry 2012, 8, 330-336. https://doi.org/10.3762/bjoc.8.36.

12. Gordon, P.; Fry, A.; Hicks, L. Further studies on the reduction of benzylic alcohols by hypophosphorous acid/iodine. ARKIVOC 2005, $2005,393-400$.

13. Deno, N. C.; Friedman, N.; Hodge, J. D.; MacKay, F. P.; Saines, G. The Hydride Transfer Nature of the Reduction of Carbonium Ions by HBr, HI and a Pt and an Ir Hydride. J. Am. Chem. Soc. 1962, 84 (24), 4713-4715. https://doi.org/10.1021/ja00883a019.

14. Pekhk, T. I.; Petrenko, A. E.; Aleksandrov, A. M.; Sorochinskii, A. E.; Golovatyi, V. G.; Kukhar', V. P. ChemInform Abstract: Bromo and Hydroxy Derivatives of Tetracyclo(6.3.0.0 $\left.0^{4,11} .0^{5,9}\right)$ undecane- 2,7-dione. ChemInform 1992, 23 (36), 2560. https://doi.org/10.1002/chin.199236121.

15. Sheldrick, G. A short history of SHELX. Acta Crystallographica Section A 2008, 64 (1), 112-122. https://doi.org/10.1107/S0108767307043930.

Received: 12.12.2019

Revised: 10.01.2020

Accepted: 27.02 .2020 